\title{
ACTIVATION OF THE ALTERNATIVE COMPLEMENT PATHWAY IN CANINE NORMAL SERUM BY PARACOCCIDIOIDES BRASILIENSIS
}

\author{
A.A.C. Bianchini; T.F. Petroni; P.F. Fedatto; R.R. Bianchini; E.J. Venancio; E.N. Itano; M.A. Ono \\ Departamento de Ciências Patológicas, Universidade Estadual de Londrina, Londrina, PR, Brasil. \\ Submitted: April 09, 2008; Returned to authors for corrections: May 27, 2008; Approved: March 13, 2009.
}

\begin{abstract}
The dimorphic fungus Paracoccidioides brasiliensis is the etiological agent of paracoccidioidomycosis, a human granulomatous disease. Recently the first case of natural disease in dogs was reported. The complement system is an important effector component of humoral immunity against infectious agents. Therefore, the aim of this study was to evaluate the activation of the dog alternative complement pathway by $P$. brasiliensis. Initially, the ability of erythrocytes of guinea pig, rabbit, sheep, chicken and swine to activate the dog alternative pathway was evaluated. The guinea pig erythrocytes showed the greatest capacity to activate dog alternative pathway. The alternative (AH50) hemolytic activity was evaluated in 27 serum samples from healthy dogs and the mean values were $87.2 \mathrm{AH} 50 / \mathrm{ml}$. No significant differences were observed in relation to sex and age. The alternative pathway activation by $P$. brasiliensis was higher in serum samples from adult dogs when compared to puppies and aged dogs $(\mathrm{p} \leq 0.05)$. This is the first report of dog alternative complement pathway activation by $P$. brasiliensis and suggests that it may play a protective role in canine paracoccidioidomycosis.
\end{abstract}

Key words: Paracoccidioidomycosis, dog, complement

\section{INTRODUCTION}

Paracoccidioides brasiliensis is the etiologic agent of paracoccidioidomycosis, a systemic mycosis prevalent in Latin America. The fungus grows as mycelia when cultured at $25^{\circ} \mathrm{C}$ or as yeast when cultured at $37^{\circ} \mathrm{C}$ or at the host. Male agricultural workers are most affected by the disease and the infection probably occurs by inhalation of fungus propagules $(3,5)$.

Epidemiological studies have demonstrated that infection by $P$. brasiliensis occurs in domestic and in wild animals $(6,7,8,11$, $15,18,22,24,25)$. A high frequency of infection was observed in dogs from areas endemic for paracoccidioidomycosis in Brazil $(18,24)$, although to date, only two cases of natural disease have been reported $(4,12)$.

The dog habit of sniffing and digging the soil, the probable $P$. brasiliensis habitat, may increase the risk of infection. The low frequency of natural disease in dogs may be due to failure in diagnosis or to natural resistance.
The complement system is an important immune effector mechanism against infectious agents (14) and the activation of the complement has been reported in human paracoccidioidomycosis and other mycosis $(16,17,21,23,27)$. Therefore, the aim of this study was to evaluate the activation of the canine alternative complement pathway by $P$. brasiliensis.

\section{MATERIALS AND METHODS}

\section{Serum samples}

A total of 27 serum samples were obtained from apparently healthy dogs with ages ranging from 1 to 15 years. The blood was collected by venous puncture in sterile glass tube and centrifuged within 1 hour of collection. The serum samples were stored at $-80^{\circ} \mathrm{C}$ until use. All the samples were negative to IgM and $\mathrm{IgG}$ against $P$. brasiliensis $\mathrm{gp} 43$ by the ELISA test, performed as previously described (9).

*Corresponding Author. Mailing address: Universidade Estadual de Londrina, Departamento de Ciências Patológicas, Laboratório de Imunologia Animal, Centro de Ciências Biológicas. 86051990. Campus Universitário, Londrina, Paraná. Fax: 55433371 4267. E-mail: marioono@uel.br 


\section{P. brasiliensis}

The $P$. brasiliensis isolate B-339 was cultivated on Sabouraud Dextrose Agar for seven days at $35^{\circ} \mathrm{C}$. The yeast cells were collected in PBS and killed by autoclave $\left(121^{\circ} \mathrm{C}\right.$ for $15 \mathrm{~min}$.).

Activation of the dog alternative complement pathway by erythrocytes from different animal species

Blood samples were collected from chicken, guinea pig, rabbit, sheep and swine and maintained in Alsever's solution at $4^{\circ} \mathrm{C}$ until use. Erythrocyte suspensions $(2.8 \%)$ in borate buffer saline containing $0.5 \mathrm{mM} \mathrm{Mg}{ }^{2+}$ and $0.03 \mathrm{M}$ EGTA (BBS-MgEGTA) were incubated with dog serum (diluted 1:5) for $30 \mathrm{~min}$. at $37^{\circ} \mathrm{C}$. After centrifugation $(2.000 \mathrm{xg})$ the supernatants were analyzed in a Microplate Reader at $492 \mathrm{~nm}$. The percentage of lysis was calculated in relation to the $100 \%$ lysis control (erythrocyte suspension and distilled water).

Evaluation of alternative complement pathway activity in dog serum samples and alternative complement pathway activation by $\boldsymbol{P}$. brasiliensis

The alternative complement pathway activity (AH50) was evaluated by a micromethod (20) using guinea pig erythrocytes. The serum samples diluted 1:10 in BBS-Mg-EGTA were added to $1.5 \mathrm{~mL}$ microcentrifuge tubes at volumes of 40, 60, 80 and $100 \mu \mathrm{l}$ and the final volume was completed with BBS-Mg-EGTA. The $2.8 \%$ suspension of guinea pig erythrocytes was added $(100 \mu \mathrm{l})$ and after incubation for $30 \mathrm{~min}$. at $37^{\circ} \mathrm{C}$, the tubes were centrifuged $(2.000 \mathrm{xg})$ and the supernatants were analyzed in a Microplate reader at $492 \mathrm{~nm}$. The percentage of lysis was calculated in relation to $100 \%$ lysis control (erythrocyte suspension and distilled water) and plotted in a graph for AH50 determination.

The evaluation of alternative complement pathway activation by $P$. brasiliensis yeast cells was performed by determination of AH50, as described above, in serum samples preincubated with inactivated $P$. brasiliensis yeast cells $\left(2 \times 10^{5}\right.$ cells in BBS-Mg-EGTA), for $30 \mathrm{~min}$. at $37^{\circ} \mathrm{C}$ in an orbital shaker (100 rpm). As control, the serum samples were preincubated for the same time with BBS-Mg-EGTA only. The alternative complement activation was determined as follows: AH50/ml in serum sample - AH50/ml in serum sample preincubated with $P$. brasiliensis.

\section{Statistical analysis}

The data were analyzed by ANOVA and the Tukey-Kramer test (STATISTIC 6.0). The difference was considered significant when $\mathrm{P} \leq 0.05$.

\section{RESULTS AND DISCUSSION}

As a preliminary study, the most adequate erythrocyte for canine alternative pathway activation was evaluated.
Erythrocytes from sheep, chicken, rabbit, swine and guinea pigs were assayed. Guinea pig erythrocytes showed the highest efficiency for alternative pathway activation and hence they were used for AH50 determination (Fig. 1).

Tanaka et al. (26) evaluated the activation of dog alternative complement pathway by erythrocytes from different animal species and the swine erythrocytes showed higher activation efficiency than guinea pig and rabbit erythrocytes (26). The disagreement observed was probably due to differences between the methodologies used in both studies. Taking into account that the guinea pig erythrocyte is more easily available than swine erythrocytes, this result makes the alternative complement evaluation in dog serum more suitable.

The alternative complement activity evaluated in serum samples showed an average of $87.2 \pm 51.9 \mathrm{AH} 50 / \mathrm{ml}$ and no significant difference was observed in relation to gender or age (Table 1).

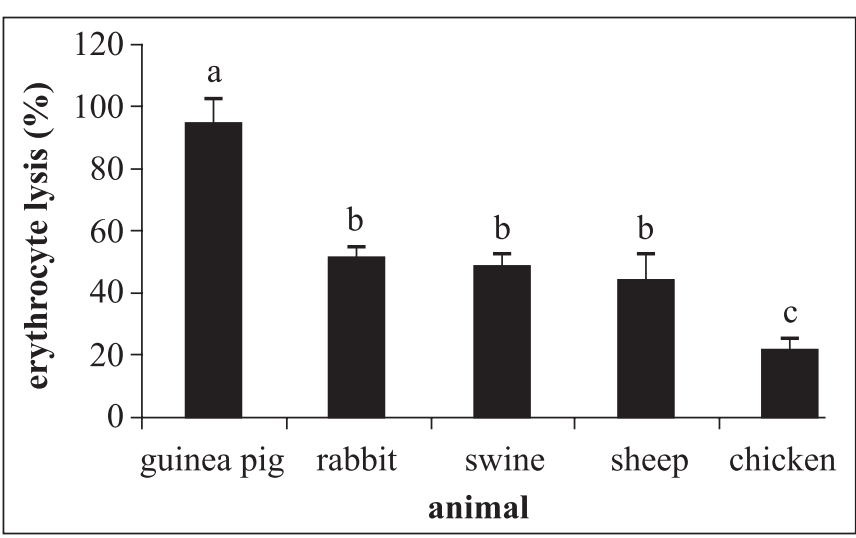

Figure 1. Activation of the dog alternative complement pathway by erythrocytes from different animal species.

Bars with different letters indicate statistically difference $(\mathrm{P} \leq 0.05)$

Table 1. Alternative complement activity in dogs' serum samples according to sex and age.

\begin{tabular}{cc}
\hline & AH50/ml \\
\hline Sex & \\
Male $(\mathrm{n}=16)$ & $80.9 \pm 53.6$ \\
Female $(\mathrm{n}=11)$ & $96.3 \pm 50.6$ \\
\hline Age $($ years $)$ & \\
$<1(\mathrm{n}=8)$ & $67.9 \pm 52,8$ \\
$1-8(\mathrm{n}=10)$ & $88.8 \pm 54.9$ \\
$9-15(\mathrm{n}=9)$ & $101.1 \pm 52.0$ \\
\hline Total $(\mathrm{n}=27)$ & $87.2 \pm 51.9$ \\
\hline
\end{tabular}


Taking into account that the complement is an important effector mechanism against fungal infection (12) in this study the activation of the dog alternative complement pathway by $P$. brasiliensis was evaluated. The alternative pathway activation in dogs aged between 1 to 8 years was significantly higher than animals up to 1 year and animals over 9 years old (Fig. 2).

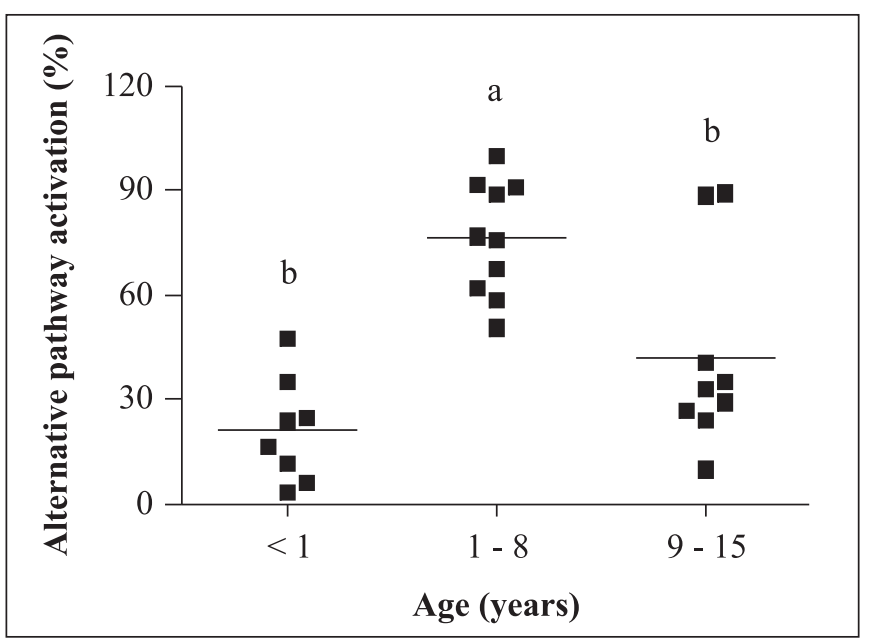

Figure 2. Activation of the alternative complement pathway by $P$. brasiliensis in serum samples from dogs with different ages. Different letters indicate statistically difference $(\mathrm{P} \leq 0.05)$.

The immune response in the very young and very old dogs is impaired as well as in other animal species $(1,2,10,13)$.

Other studies have described the activation of the alternative complement pathway by fungus such as Sporothrix schenckii, Histoplasma capsulatum and Blastomyces dermatitidis $(21,23,27)$. The complement activation also has been reported in human patients with paracoccidioidomycosis $(14,16)$ and another study showed that $P$. brasiliensis yeast cells could activate the complement in human normal serum (17).

The high frequency of infection by $P$. brasiliensis observed in dogs living in paracoccidioidomycosis endemic areas, the low incidence of natural disease reported in this species and experimental data with adult animals suggest that adult dogs are resistant to the development of paracoccidioidomycosis $(18,24)$.

Our group has observed, in studies on experimental paracoccidioidomycosis in dogs aged three months (19) and adult (9), that probably puppies are susceptible and adults are resistant to disease development. The results of this study are in agreement with these data, taking into account that the activation of the alternative complement pathway by $P$. brasiliensis was higher in adult dogs than those under one year old.
This is the first report that $P$. brasiliensis activates canine alternative complement pathway and suggests that it can play a protective role.

\section{ACKNOWLEDGEMENTS}

The authors thank CAPES and Araucaria Foundation for financial support and $\mathrm{CNPq}$ for the productivity fellowship granted to M.A. Ono.

\section{RESUMO}

\section{Ativação da via alternativa do complemento em soro de cão normal por Paracoccidioides brasiliensis}

O fungo dimórfico Paracoccidioides brasiliensis é o agente etiológico da paracoccidioidomicose, uma doença granulomatosa humana. Recentemente, foi relatado o primeiro caso da doença natural em cães. O sistema complemento é um importante componente efetor da imunidade humoral contra agentes infecciosos. Portanto, o objetivo deste trabalho foi avaliar a ativação da via alternativa do complemento canina pelo $P$. brasiliensis. Inicialmente, foi avaliada a capacidade de eritrócitos de cobaia, coelho, carneiro, galinha e suíno ativarem a via alternativa do complemento canino. Os eritrócitos de cobaia apresentaram maior capacidade de ativar a via alternative do complemento canino. A atividade hemolítica da via alternativa (AH50) foi avaliada em 27 amostras de soro de cães saldáveis e os valores médios observados foram de 87,2 AH50/ml. Não foi observada diferença significativa ao sexo e idade. A ativação da via alternativa pelo $P$. brasiliensis foi maior nas amostras de soro de cães adultos quando comparada aos cães filhotes e idosos (p $\leq 0.05$ ). Este é o primeiro relato da ativação da via alternative do complemento canino pelo fungo $P$. brasiliensis e sugere que pode ter um papel protetor na paracoccidioidomicose canina.

Palavras-chave: Paracoccidioidomicose, cão, complemento

\section{REFERENCES}

1. Adkins, B.; Du, R.Q. (1998). Newborn mice develop balanced Th1/ Th2 primary effector responses in vivo but are biased to Th2 secondary responses. J. Immunol., 160, 4217-24.

2. Aw, D.; Silva, A.B.; Palmer, D.B. (2007). Immunosenescence: emerging challenges for an ageing population. Immunology, 120, 435-46.

3. Blotta, M.H.S.L.; Camargo, Z.P. (1993). Immunological Response to Cell-Free Antigens of Paracoccidioides brasiliensis: Relationship with clinical forms of Paracoccidioidomycosis. J. Clin. Microbiol., 31, 671-676.

4. Bosco, S.M.G.; Theodoro, R.C.; Macoris, S.A.G.; Farias, M.R.; Muro, M.; Ribeiro, M.G.; Bagagli, E. (2005). Morphological and molecular characterization of the first isolate of Paracoccidioides brasiliensis from dog (Canis familiaris). Rev. Inst. Med. Trop. S. Paulo, 47 suppl. 14, 62-63. 
5. Brummer, S.O.; Castaneda, E.; Restrepo, A. (1993). Paracoccidioidomycosis: an update. Clin. Microbiol. Rev., 6, 89117.

6. Conti-Diaz, I.A.; Alvarez, B.J.; Gezuele, E.; Marini, H.G.; Duarte, J.; Falcón, J. (1972). Encuesta mediante intradermoreactiones con paracoccidioidina y histoplasmina en caballos. Rev. Inst. Med. Trop. S. Paulo, 14, 372-376.

7. Corte, A.C.; Svoboda, W.K.; Navarro, I.T.; Freire, R.L.; Malanski, L.S.; Shiozawa, M.M.; Ludwig, G.; Aguiar, L.M.; Passos, F.C.; Maron, A.; Camargo, Z.P.; Itano, E.N.; Ono, M.A. (2007) Paracoccidioidomycosis in wild monkeys from Paraná State, Brazil. Mycopathologia, 164, 225-228.

8. Costa, E.O.; Diniz, L.S.M.; Fava-Netto, C. Arruda, C.; Dagli, M.L. (1995). Delayed hypersensitivity test with paracoccidioidin in captive Latin American wild animals. J. Med. Vet. Mycol., 33, 39-42.

9. Eisele, R.C.; Juliani, L.C.; Belitardo, D.R.; Itano, E.N.; Estevão, D.; Bracarense, A.P.F.R.L.; Camargo, Z.P.; Ono, M.A. (2004). Immune response in dogs experimentally infected with Paracoccidioides brasiliensis. Med. Mycol., 42, 549-553.

10. Greeley, E.H.; Ballam, J.M.; Harrison, J.M.; Kealy, R.D.; Lawler, D.F.; Segre, M. (2001). The influence of age and gender on the immune system: a longitudinal study in Labrador Retriever dogs. Vet. Immunol. Immunopathol., 82, 57-71.

11. Gutierrez, A.H.; Ceballos, G.C.; Ferrer, H.I.P.; Rangel, O. (1974). Encuesta sobre tuberculosis, histoplasmosis y paracoccidioidomicosis en ganado lechero del Valle del Aburra. Antioq. Med. 24, 339-358.

12. Kozel, T.R. (1996). Activation of the complement system by pathogenic fungi. Clin. Microbiol. Rev., 9, 34-46.

13. Maródi, L. (2006). Neonatal innate immunity to infectious agents. Infect Immun., 74, 1999-2006.

14. Messias, I.T.; Mohren, D. (1994). Classical and alternative complement pathway activation in paracoccidioidomycosis. $J$. Investig. Allergol. Clin. Immunol., 4, 91-95.

15. Mós, E.N.; Fava Netto, C. (1974). Contribuição ao estudo da paracoccidioidomicose. I. Possível papel epidemiológico dos cães. Estudo sorológico e anatomo-patológico. Rev. Inst. Med. Trop. S Paulo, 16, 154-159.
16. Munk, M.E.; Kajdacsy-Balla, A.; Del Negro, G.; Cuce, L.C.; Da Silva, W.D. (1992). Activation of human complement system in paracoccidioidomycosis. J. Med. Vet. Mycol., 30, 317-321.

17. Munk, M.E.; Silva, W.D. (1992). Activation of human complement system Paracoccidioides brasiliensis and its deposition on the yeast form cell surface. J. Med. Vet. Mycol., 30, 481-484.

18. Ono, M.A.; Bracarense, A.P.F.R.L.; Morais, H.S.A. Trapp, S.M.; Belitardo, D.R.; Camargo, Z.P. (2001). Canine paracoccidioidomycosis: A seroepidemiologic study. Med. Mycol., 39, 277-282.

19. Ono, M.A.; Kishima, M.O.; Itano, E.N.; Bracarense, A.P.F.R.L., Camargo, Z.P. (2003). Experimental paracoccidioidomycosis in dogs. Med. Mycol., 41: 265-268.

20. Phimister, G.M.; Whaley, K. (1990). Measurement of complement In: Clinical Immunology: A practical approach. GOOI \& CHAPEL, H. Oxford University Press, New York, p. 263.

21. Ratnoff, W.D.; Pepple, J.M.; Winkelstein, J.A. (1980). Activation of the alternative complement pathway by Histoplasma capsulatum. Infect. Immun., 30, 147-149.

22. Ricci, G.; Mota, F.T.; Wakamatsu, A.; Serafim, R.C.; Borra, R.C.; Franco, M. (2004). Canine paracoccidioidomycosis. Med. Mycol., 42, 379-383.

23. Scott, E.N.; Muchmore, H.G.; Fine, D.P. (1986). Activation of the alternative complement pathway by Sporothrix schenckii. Infect. Immun., 51, 6-9.

24. Silveira, L.H.; Domingos, I.H.; Kouchi, K.; Itano, E.N.; Silva, E.A.; Landgraf, V.O.; Werneck, S.M.; Camargo, Z.P.; Ono, M.A. (2006). Serological detection of antibodies against Paracoccidioides brasiliensis in dogs with leishmaniasis. Mycopathologia, 162, 325-329.

25. Silveira, L.H.; Paes, R.C.S.; Medeiros, E.V.; Itano, E.N.; Camargo, Z.P.; Ono M.A. (2008). Occurrence of antibodies to Paracoccidioides brasiliensis in dairy cattle from Mato Grosso do Sul, Brazil Mycopathologia, 165, 367-371.

26. Tanaka, S.; Kitamura, F.; Suzuki, T. (1987). Studies on the hemolytic activity of the classical and alternative pathway of complement in various animal species. Complement, 4, 33-41.

27. Zhang, M.X.; Klein, B. (1997). Activation, binding, and processing of complement component 3 (C3) by Blastomyces dermatitidis. Infect. Immun., 65: 1849-55. 